\title{
PRELIMINARY SUB-SYSTEMS DESIGN INTEGRATED IN A MULTIDISCIPLINARY DESIGN OPTIMIZATION FRAMEWORK
}

\author{
Marco Fioriti, Luca Boggero, Sabrina Corpino \\ Department of Mechanical and Aerospace Engineering, Politecnico di Torino, C.so Duca degli Abruzzi n.24, \\ Turin, Italy \\ marco.fioriti@polito.it, luca.boggero@polito.it, sabrina.corpino@polito.it
}

\section{Abstract}

The aircraft design is a complex subject since several and completely different design disciplines are involved in the project. Many efforts are made to harmonize and optimize the design trying to combine all disciplines together at the same level of detail. Within the ongoing AGILE (Horizon 2020) research, an aircraft MDO (Multidisciplinary Design Optimization) process is setting up connecting several design tools and competences together. Each tool covers a different design discipline such as aerodynamics, structure, propulsion and systems. This paper focuses on the integration of the sub-system design discipline with the others in order to obtain a complete and optimized aircraft preliminary design. All design parameters used to integrate the sub-system branch with the others are discussed as for their redefinition within the different detail level of the design.

Keywords: Multidisciplinary Design Optimization, Aircraft Sub-system Design, Design Space Parameters.

\section{INTRODUCTION}

The aircraft initial design is one of the most important phases of aircraft development since in a short time engineers have to mature a competitive and innovative product that should be considered nearly defined at the end of this phase. The development of an advanced and competitive aircraft should include MDO (Multidisciplinary Design Optimization) techniques to reduce the convergence time and to obtain an optimized design considering all main disciplines in a harmonized way [1]. The final result should be a design more globally optimized than older projects, in which a local optimization inside each technical specialties were pursued. The main difficulty in following this approach is to face the usual and unavoidable conflict between disciplines where the optimal 
solution in one specialty implies a lacking design for the others. Several European projects - e.g. AGILE [2], SimSAC [3], VIVACE [4], CESAR [5], CRESCENDO [6] and TOICA [7] - are aimed at investigating and developing methods to support the collaboration among the several disciplinary experts involved within the aircraft design and optimization process. The strong interaction among all the design disciplines is well underlined in the definition of MDO provided by Sobieski [8]: a MDO is "a methodology for a design of complex engineering systems that are governed by mutually interacting physical phenomena and made up of distinct interacting subsystems (suitable for systems for which) in their design, everything influences everything else". Indeed, a MDO problem is characterized by a certain number of design variables that are managed by an optimizer [9]. Those variables constitute the design space and they may be divided among "local" and "shared" variables. The first set of parameters regards only a single discipline, while the latter pertains all the disciplines.

Hence, the main aim of this paper is to define and explain which parameters of the design space should be used as interface between the preliminary sub-systems design and the other specialties. In other words, which design variables are shared and have an impact on sub-systems and on other design disciplines.

It is well known and recognized that on-board systems have a strong impact on the overall aircraft. The three pie chart in Fig. 1 clearly shows a deep influence of mass, cost and maintenance actions of sub-systems compared with the entire airplane. According to Liscouët-Hanke [10], aircraft on-board systems represent about the $30 \%$ of the aircraft empty weight and development, operation and direct maintenance costs (see Fig. 2). In support of this, Prof. Scholz stated [11] that the percentage of sub-systems weight on the overall empty weight ranges from $23 \%$ (in the case of modern long-range civil aircraft) up to $40 \%$ considering smaller airplanes as business jets. Even fuel consumption is affected by aircraft systems: a non-negligible part of the total power produced by the engines is supplied to on-board systems, hence influencing the quantity of fuel burnt during the flight, as about $5 \%$ of the total fuel is consumed for secondary power [12]. Moreover, systems design has an impact also on aircraft drag, hence impacting the performances of the overall airplane [13]. For instance, in a civil transport aircraft ACM (Air Cycle Machines) are typically installed in the belly of the fuselage, ahead of the wings, affecting the shape of the fuselage. Another example is given by the flaps fairing in which flap kinematics are hosted, with an impact on the aerodynamics [14].

The design parameters must change with the level of the design detail as for tools and specialties involved. Furthermore, this paper is focused on the impact of sub-systems technologies and architectures, such as more or all electric, on other disciplines. The defined design parameters range from the sub-systems weight, volume, performances to the engine power off-takes required as secondary power with an increasing level of details. During the first design iterations, the sub-systems are globally considered. Afterwards, also the main equipment of each sub-system is taken into account.

In the second section, the parameters needed to carry out the on-board system design are described in terms of typology and impact on the other design disciplines typically considered in aircraft conceptual design. In section three the same analysis are made increasing the detail level of design considering the main on-board systems and their effects on disciplines, such as aerodynamics, structures, aeroelastics, loads, flight mechanics, flight control, propulsion, RAMS (Reliability Availability Maintainability Safety) and cost which are all regarded during the preliminary design. 


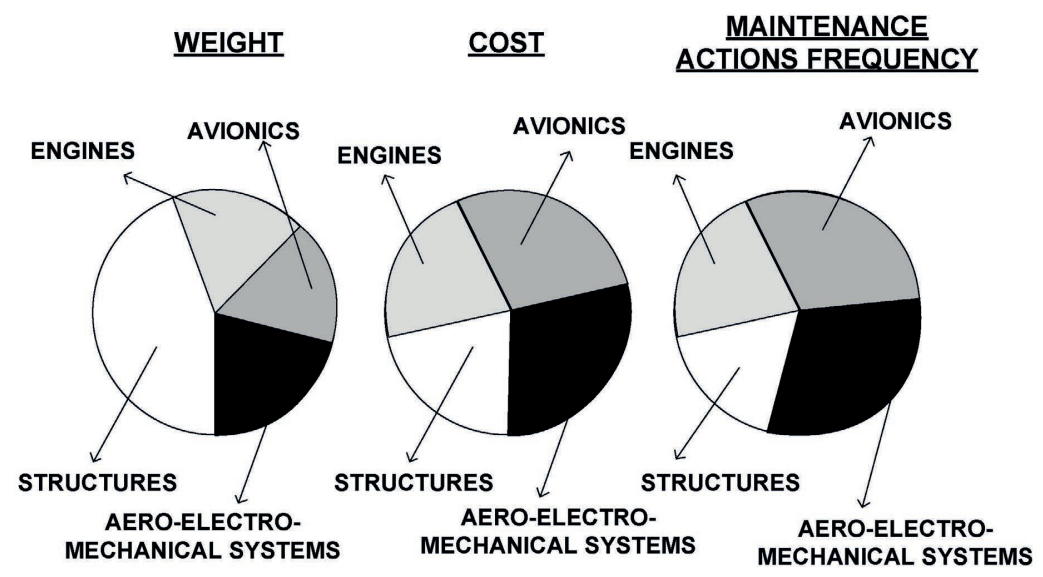

Fig. 1. Importance of aircraft system in the overall design [own study].

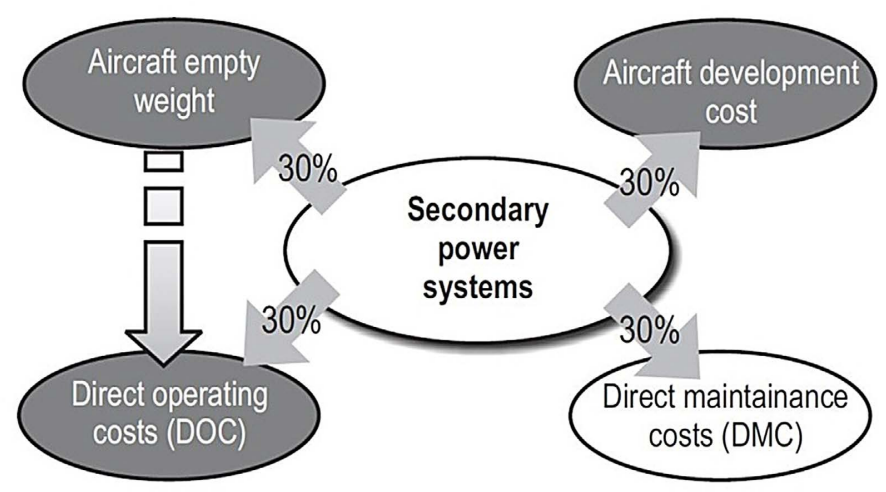

Fig. 2. Effects of systems on aicraft empty weight and costs (adapted from [10]).

\section{ON-BOARD SYSTEMS DESIGN VARIABLES IN AIRCRAFT CONCEPTUAL DESIGN}

Throughout the first phase of aircraft conceptual design (see Fig. 3 [15]), on-board systems are usually considered for their weight [15], [16], [17], [18]. This is due to the great importance of the convergence of aircraft weight during conceptual design. Generally, the weight estimation is one of the first steps necessary to define the feasibility of a specified design for an aerospace product.

At the beginning of the design, the information related to the on-board systems is not highly detailed. The associated requirements are represented by systems functionalities, weight constraints and both standards and regulations compliancy which are usually consistent with the designated aircraft class. Therefore, the weight of each system can be estimated as fractions of MTOM (Maximum takeoff mass) or OEM (Operating empty weight) during this phase of the design. The values of these fractions strictly depend on aircraft category and on-board system technology 
used (i.e. standard or more electric technology) and their complexity (e.g. high lift devices of a STOL (Short take-off and landing) aircraft is more complex than standard aircraft and usually weight more). An example of these fractions can be found in Table 1 [18]. Typically, the weight fractions are derived from statistical data. The engineer in the conceptual design should assess the obtained results comparing them to the data of an existing aircraft. However, this is possible only in the design of traditional aircraft, while for innovative concepts (e.g. blended wing body, More/All Electric Aircraft [19], [20], etc.) statistical data are not present. In these cases, the designer should tune and adjust the weight fractions on the basis of his personal knowledge and background. As instance, the hydraulic weigh coefficient should be set to zero in the design of an "all electric aircraft", hence increasing the value of the electric weight fraction, taking into account the increment of electric power demand and so entailing heavier generation and distribution systems. More affordable results will be obtained in the second design iteration (i.e. preliminary design), in which more physics-based methodologies will be employed. The systems weight strongly influence the aircraft weight and its performance during the designed mission profile.

Table 1. MTOM fractions for aircraft on-board systems [18]

\begin{tabular}{|l|c|l|}
\hline Aircraft System & Coefficient range & \multicolumn{1}{c|}{ Rationale } \\
\hline Landing gear system & $0.022 \div 0.045$ & Complexity (fixed or retractable) \\
\hline Flight control system & $0.015 \div 0.04$ & Complexity (flight control) \\
\hline Hydraulic system & $0.005 \div 0.03$ & Complexity (flight control and landing gear) \\
\hline Electric system & $0.020 \div 0.04$ & Complexity (flight control and avionics) \\
\hline Fuel system & $0.015 \div 0.02$ & n. engines and presence of after burner \\
\hline Air conditioning system & $0.005 \div 0.07$ & n. passengers \\
\hline Avionic system & $0.030 \div 0.06$ & Aircraft role (transport, trainer, fighter, multirole) \\
\hline Engine system & $0.005 \div 0.015$ & n. engines \\
\hline Furnishing & $0.005 \div 0.04$ & Passenger comfort and flight duration \\
\hline
\end{tabular}

Another important design parameter is the global center of gravity (C.G.) position of the on-board systems. This parameter affects the stability of the aircraft and frequently it is assumed in the same position of the global C.G. as first attempt. This preliminary assumption is supported by the equal distribution of the systems along fuselage and wing. In some cases, when large equipment and/or sensors are part of the design (e.g. surveillance aircraft such as UAV, AEW, EW etc.), their C.G. position should be taken into account at the stage of the conceptual design.

The engine power off-takes required by on-board systems is a design variable that impacts primarily the fuel weight and hence the aircraft MTOM. Also, for this parameter the information is not enough detailed to perform an estimation starting from the actual systems power required. In this phase, the secondary power is not yet estimated, and so the systems power off-take can be assumed as a fraction of the total power or thrust produced by the engines. Alternatively, the fuel consumed by the systems is assumed to be a percentage of the total required fuel. This percentage typically ranges around 5\% [11], but this value could be lower as for innovative architectures [21]. Moreover, the engine power off-takes influence the engine efficiency modifying the first assumption on engine specific fuel consumption (SFC). 
The systems volume could become a notable variable in conceptual design when large equipment and sensors is needed to carry out the mission of the aircraft. As previously said for C.G. position, the volume of sensors such as AEW radar antenna, electroptic turret, electronic warfare antenna usually installed on surveillance aircraft represents an important parameter concerning aircraft architecture, aerodynamics and performance. The volume of these sensors is typically too large to be installed inside the aircraft hence it represents an increment of aircraft drag. Also weapon system (not considered in this paper) for military aircraft and the furnishing for liner could be seen and evaluated as for sensors.

The on-board system parameters and their effects on conceptual aircraft design disciplines (see Fig. 3) are summarized in Table 2.

Table 2. On-board system design variables in aircraft conceptual design. Effects on conceptual aircraft design disciplines [own study]

\begin{tabular}{|c|c|c|c|c|c|}
\hline & Initial layout & $\begin{array}{l}\text { Aerodynamics } \\
\text { and Stability }\end{array}$ & $\begin{array}{l}\text { Weight } \\
\text { estimation }\end{array}$ & Propulsion & Performance \\
\hline $\begin{array}{l}\text { On-board } \\
\text { system } \\
\text { variables in } \\
\text { aircraft } \\
\text { conceptual } \\
\text { design }\end{array}$ & $\begin{array}{l}\text { - Volume of } \\
\text { large } \\
\text { equipment } \\
\text { and/or } \\
\text { sensors }\end{array}$ & $\begin{array}{l}\text { - Volume of } \\
\text { large } \\
\text { equipment } \\
\text { and/or } \\
\text { sensors } \\
\text { - Systems } \\
\text { C.G. } \\
\text { position }\end{array}$ & $\begin{array}{l}\text { - Systems } \\
\text { weight } \\
\text { - Systems } \\
\text { power off- } \\
\text { takes }\end{array}$ & $\begin{array}{l}\text { - Systems } \\
\text { power off- } \\
\text { takes }\end{array}$ & $\begin{array}{l}\text { - Systems } \\
\text { weight } \\
\text { - Systems } \\
\text { power off- } \\
\text { takes } \\
\text { - Volume of } \\
\text { large } \\
\text { equipment } \\
\text { and/or } \\
\text { sensors }\end{array}$ \\
\hline
\end{tabular}

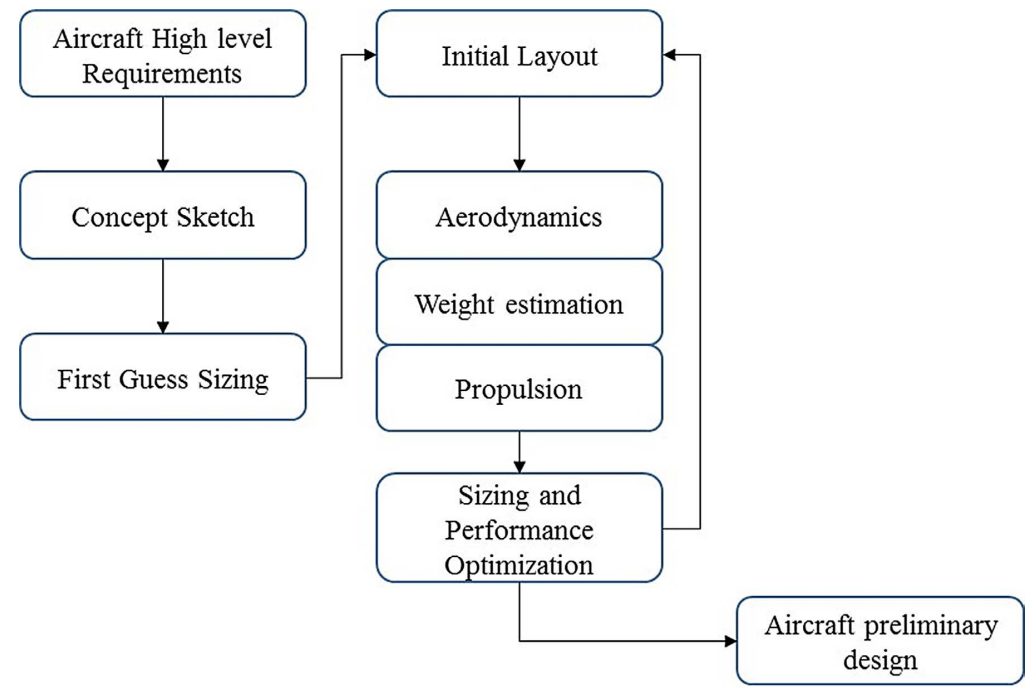

Fig. 3. Aircraft conceptual design process [15]. 


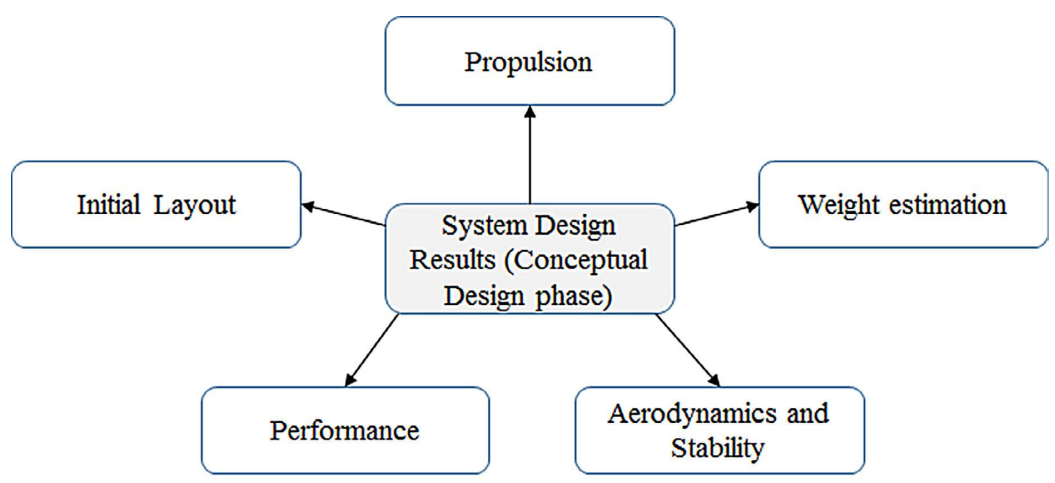

Fig. 4. Effects of systems conceptual design results on OAD [own study].

The effects on the OAD (Overall Aircraft Design) of the results of systems conceptual design are also schematically depicted in Fig. 4. The preliminary systems weight estimation affects already in the conceptual design the sizing of structures and, in some cases, the initial layout. Furthermore, the preliminary estimations of the masses and the positions of systems are exploited in the flight mechanics and performance disciplines, hence obtaining the first evaluation of the aircraft gravity center location. Finally, the total fuel quantity is increased by taking into account the first estimation of fuel required by the on-board systems, which has also an effect on the engine efficiency.

\section{ON-BOARD SYSTEMS DESIGN VARIABLES IN AIRCRAFT PRELIMINARY DESIGN}

Once initial aircraft results are obtained from the conceptual design, the development process proceeds with the preliminary design, in which more knowledge about the future product is acquired and hence more affordable results are achieved.

The on-board systems design makes use of more physics-based methodologies, even if statistical equations are still considered. The "systems design" discipline is well integrated among all the specialties, since the high number of shared and influenced variables (see Fig. 5). Many inputs required by the systems design derive from the $\mathrm{OAD}$, as masses, aircraft performances, top level aircraft requirements, mission profiles and others. In the same way, aircraft sub-system results affect the overall aircraft, as mentioned in the introductive section. Going into details, the preliminary design of on-board systems allows mainly the evaluation of masses (of both sub-systems and the main components), the main equipment volumes and locations and required power off-takes (mechanical, electric and hydraulic) and airflow bled from engine compressors. All those outcomes affect all the other design disciplines, as schematically shown in the subsequent tables (from Table 3 to Table 9) and discussed below. Commonly, each system design parameter produces an effect on every other discipline. However, for the sake of clarity, between all design parameters, the merely reported ones are those that produce an important effect on the other design domains. 


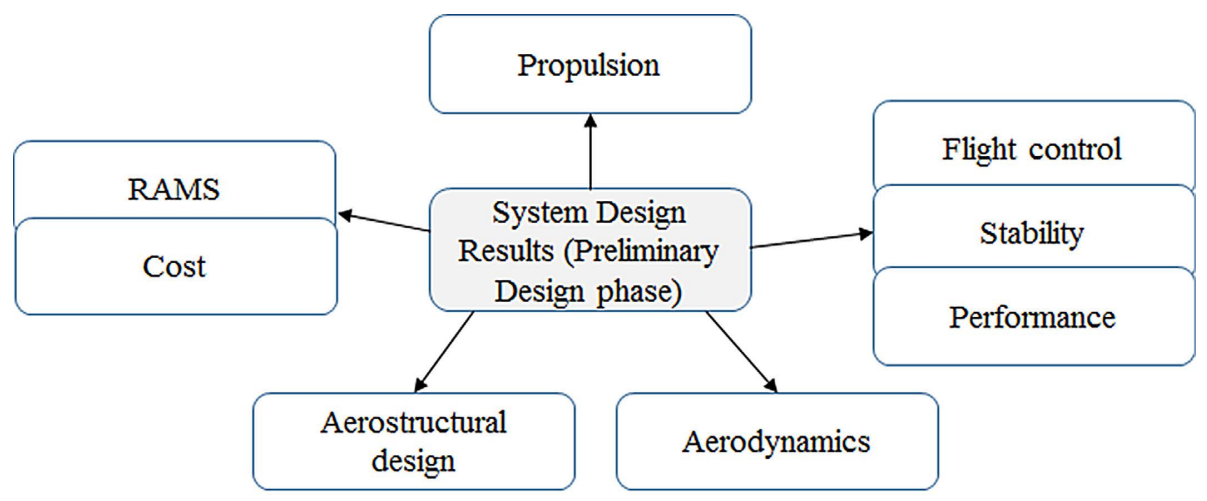

Fig. 5. Effects of systems preliminary design results on OAD [own study].

Considering the avionic system (see Table 3), once all regulation requirements are complied, there are additional functionalities and redundancies that can be considered during the design. Therefore, selecting not-mandatory equipment such as FBW (Fly by wire), modern AFDS (Autopilot / Flight director system) and FMS (Flight Management System), it is possible to obtain several functionalities that most affect the other disciplines. The gust alleviation and aircraft flight envelope protection functionalities contribute to reducing structural load and consequently structure weight. The aircraft handling qualities and trajectory can be optimized by the equipment resulting in a more efficient maneuvers. This implies a reduction of associated drag, hence a reduction of burnt fuel. On the other hand, more functionalities indicate more equipment, thus an increment in the system's weight, acquisition and maintenance cost. The redundancy level is another variable for the avionic systems that heavily impacts the system's total weight and the required power allowing for a higher level of safety when it increases.

The Flight Control System design is mainly characterized by the sizing of the actuators of mobile surfaces (see Table 4). Traditional $20,684 \mathrm{kPa}$ hydraulic or $28 \mathrm{~V} \mathrm{DC}$ electric actuators are currently being replaced by systems characterized by higher pressure supply $(34,473 \mathrm{kPa})$ [22] or higher electric voltages (e.g. $270 \mathrm{~V} \mathrm{DC}$ and $235 \mathrm{~V} \mathrm{AC}$ wild frequency). The aim of those new technologies is the reduction of the actuators weight and volume [23], hence entailing benefits from aerodynamic and structural points of view. However, at the moment, electric actuators require more volume than hydraulic one varying the effect on wing design or fairing. Nonetheless, the More/All Electric Aircraft philosophy pushes towards a more effective secondary power consumption, hence reducing the amount of fuel required to supply the actuators. Furthermore, benefits in terms of the maintenance costs are obtained, as hydraulic specialists are not needed [24]. However, some negative effects could result in increasing acquisition costs of the actuation equipment due to a high development cost of this innovative product [25]. Then, the design choice concerning the number of flight control lines and actuators per mobile surface results in system weight variations. This design variable is then responsible of an increment or a reduction of flight control safety level. Finally, performance of the installed actuators, in particular relative to the actuation speed, modify the flight handling qualities as for the dynamic loads. 
Table 3. Avionic system design variables in aircraft preliminary design. Effects on aircraft design disciplines [own study]

\begin{tabular}{|c|c|c|c|c|c|}
\hline Avionic system & Aerodynamics & $\begin{array}{l}\text { Aerostructural } \\
\text { design }\end{array}$ & $\begin{array}{l}\text { Flight control, } \\
\text { stability and } \\
\text { performance }\end{array}$ & Propulsion & RAMS / Cost \\
\hline $\begin{array}{l}\text { Functionalities } \\
\text { selection }\end{array}$ & $\begin{array}{l}\text { - Volume of } \\
\text { large } \\
\text { equipment } \\
\text { and/or } \\
\text { sensors }\end{array}$ & $\begin{array}{l}\text { - Equipment } \\
\text { weight } \\
\text { - Gust } \\
\text { alleviation } \\
\text { - Flight } \\
\text { envelope } \\
\text { protection }\end{array}$ & $\begin{array}{l}\text { - Stability } \\
\text { control via } \\
\text { FBW } \\
\text { - Handling } \\
\text { qualities } \\
\text { control via } \\
\text { FBW } \\
\text { - Optimization } \\
\text { of trajectories }\end{array}$ & $\begin{array}{l}\text { - Optimization } \\
\text { of propulsive } \\
\text { power }\end{array}$ & $\begin{array}{l}\text { - Equipment } \\
\text { cost } \\
\text { - Maintenance } \\
\text { cost } \\
\text { - Fuel cost per } \\
\text { FH }\end{array}$ \\
\hline $\begin{array}{l}\text { Amount of } \\
\text { redundant } \\
\text { equipment }\end{array}$ & & $\begin{array}{l}\text { - Equipment } \\
\text { weight }\end{array}$ & & $\begin{array}{l}\text { - Equipment } \\
\text { power } \\
\text { requirement }\end{array}$ & $\begin{array}{l}\text { - Safety level } \\
\text { - Equipment } \\
\text { cost } \\
\text { - Maintenance } \\
\text { cost }\end{array}$ \\
\hline
\end{tabular}

Table 4. Flight control system design variables in aircraft preliminary design. Effects on aircraft design disciplines [own study]

\begin{tabular}{|c|c|c|c|c|c|}
\hline $\begin{array}{l}\text { Flight Control } \\
\text { System main } \\
\text { parameter }\end{array}$ & Aerodynamics & $\begin{array}{l}\text { Aerostructural } \\
\text { design }\end{array}$ & $\begin{array}{l}\text { Flight control, } \\
\text { stability and } \\
\text { performance }\end{array}$ & Propulsion & RAMS / Cost \\
\hline $\begin{array}{l}\text { Actuator } \\
\text { technology } \\
\text { electric/ } \\
\text { hydraulic }\end{array}$ & $\begin{array}{l}\text { - Actuator } \\
\text { fairing } \\
\text { volume }\end{array}$ & $\begin{array}{l}\text { - Actuator } \\
\text { weight }\end{array}$ & & $\begin{array}{l}\text { - Actuator } \\
\text { power } \\
\text { required }\end{array}$ & $\begin{array}{l}\text { - Actuator cost } \\
\text { - Maintenance } \\
\text { cost }\end{array}$ \\
\hline $\begin{array}{l}\text { Actuator supply } \\
\text { voltage / } \\
\text { pressure }\end{array}$ & $\begin{array}{l}\text { - Actuator } \\
\text { fairing } \\
\text { volume } \\
\end{array}$ & $\begin{array}{l}\text { - Actuator } \\
\text { weight }\end{array}$ & & & \\
\hline $\begin{array}{l}\text { Number of lines } \\
\text { and actuators } \\
\text { per surfaces }\end{array}$ & & $\begin{array}{c}\text { - System } \\
\text { weight }\end{array}$ & & & $\begin{array}{l}\text { - System safety } \\
\text { (level of } \\
\text { redundancy) }\end{array}$ \\
\hline Actuator speed & & $\begin{array}{l}\text { - Dynamic } \\
\text { loads }\end{array}$ & $\begin{array}{l}\text { - Handling } \\
\text { qualities }\end{array}$ & & \\
\hline
\end{tabular}

Moving to the Landing Gear Systems (Table 5), all the parameters concerning the actuation systems (i.e. retraction, steering and braking systems) are analogous to those relative to the Flight Control Systems. Therefore, it is worth presenting an analysis about other design variables, peculiar of this kind of an on-board system. The most important design choices, due to their effects over all the other disciplines, regard the position and length of the gear struts. For instance, the aerodynamics could be highly affected by the fairings storing the retracted landing gear. Even the shaping of the tail cone results from the installation and dimensions of those systems preventing ground contacts 
during liftoff rotation manoeuver. Moreover, the landing gear length also affects the distance of the aircraft from the ground and thus the probability of damage from FOD (Foreign Object Debris). Similarly, the structures, should be properly designed to attach the struts and store the retracted gear. For instance, the wing kink is necessary when the landing gear is stored inside the wing. Additionally, the sizing of the shock absorbers contributes to alleviating loads during the landing phase. During the preliminary development phase, specialists of flight control, stability and performance should analyze the aircraft CG shift during the struts retraction and extraction. Also they have to properly size the dimensions of the elevators, as the required aerodynamic torque is affected by the distance from the main landing gear. Another design parameter assessed by the systems designer is the number of brakes, which affects the load due to deceleration during landing or rejected take-off and contributes to reducing the length of the required runway for the procedures of take-off and landing.

None of all the on-board systems affects the CG position as the Fuel System (Table 6). As the fuel weight is typically a great percentage of the MTOM, its gravity center depends on the position of the fuel tanks. It is worth reminding the unusual feature of the supersonic aircraft Concorde, consisting in changing the location of the fuel in order to compensate the shift of the neutral point passing from the subsonic regime to the supersonic one and vice-versa. Today, liners use a similar functionality to reduce the aircraft stability during cruise in order to reduce stabilizer load and related drag. Another important effect of the Fuel System regards the wing thickness, accordingly to the volume required by the fuel tanks to store all the fuel. Obviously, this affects the aerodynamics of the entire aircraft, since the wings drag is modified. The fuel pump is another component of the fuel system that can change aircraft performance. In particular, depending from the maximum fuel flow provided, the engine performance can be limited (e.g. during particular flight maneuvers or when afterburner is turned on).

Table 5. Landing gear design variables in aircraft preliminary design. Effects on aircraft design disciplines [own study]

\begin{tabular}{|c|c|c|c|c|c|}
\hline Landing Gear & Aerodynamics & $\begin{array}{l}\text { Aerostructural } \\
\text { design }\end{array}$ & $\begin{array}{l}\text { Flight control, } \\
\text { stability and } \\
\text { performance }\end{array}$ & Propulsion & RAMS / Cost \\
\hline Strut Position & $\begin{array}{l}\text { - Tail sitting } \\
\text { angle }\end{array}$ & $\begin{array}{l}\text { - Wing spars } \\
\text { position and } \\
\text { kink } \\
\text { - Fuselage } \\
\text { former } \\
\text { position }\end{array}$ & $\begin{array}{l}\text { - A/C CG } \\
\text { movement due to } \\
\text { landing gear } \\
\text { retraction } \\
\text { - Stability on- } \\
\text { ground } \\
\text { - Elevator surface }\end{array}$ & & \\
\hline Strut length & $\begin{array}{l}\text { - Ground } \\
\text { clearance } \\
\text { - Tail sitting } \\
\text { angle } \\
\text { - Landing gear } \\
\text { fairing } \\
\end{array}$ & $\begin{array}{l}\text { - Necessary } \\
\text { internal } \\
\text { volume when } \\
\text { LG retracted } \\
\text { - Load during } \\
\text { landing } \\
\end{array}$ & $\begin{array}{l}\text { - } \mathrm{A} / \mathrm{C} \mathrm{CG} \\
\text { movement due to } \\
\text { landing gear } \\
\text { retraction }\end{array}$ & & $\begin{array}{l}- \text { Damage } \\
\text { from FOD }\end{array}$ \\
\hline $\begin{array}{l}\text { Number of } \\
\text { braked wheels }\end{array}$ & & $\begin{array}{l}\text { Load during } \\
\text { deceleration }\end{array}$ & $\begin{array}{l}\text { - Landing run } \\
\text { - Accelerate/stop } \\
\text { distance }\end{array}$ & & \\
\hline
\end{tabular}


Table 6. Fuel system design variables in aircraft preliminary design. Effects on aircraft design disciplines [own study]

\begin{tabular}{|c|c|c|c|c|c|}
\hline Fuel system & Aerodynamics & $\begin{array}{l}\text { Aerostructural } \\
\text { design }\end{array}$ & $\begin{array}{l}\text { Flight control, } \\
\text { stability and } \\
\text { performance }\end{array}$ & Propulsion & RAMS / Cost \\
\hline $\begin{array}{l}\text { Number of } \\
\text { tanks and their } \\
\text { position }\end{array}$ & & $\begin{array}{l}\text { - Main spars } \\
\text { and formers } \\
\text { position }\end{array}$ & $\begin{array}{l}\text { - A/C CG } \\
\text { movement } \\
\text { due to tanks } \\
\text { empting }\end{array}$ & & \\
\hline Tanks volumes & $\begin{array}{l}\text { - Additional } \\
\text { drag due to } \\
\text { internal } \\
\text { volume } \\
\text { increment }\end{array}$ & $\begin{array}{l}\text { - Increment of } \\
\text { distributed } \\
\text { load }\end{array}$ & & & \\
\hline $\begin{array}{l}\text { Fuel flow } \\
\text { supplied by } \\
\text { pumps }\end{array}$ & & & & $\begin{array}{l}\text { - Engine } \\
\text { performance }\end{array}$ & \\
\hline
\end{tabular}

One of the most important innovations regarding the on-board systems discipline is represented by the Environmental Control System (ECS) (Table 7), as this systems has a remarkable effect on the empty weight of the airplane and on the fuel consumption [25]. A clear example is represented by the innovative electric ECS installed aboard the Boeing 787 [26]. Newest technologies allow reductions of fuel weight as they have a lower impact on engine efficiency. In fact, these so-called "bleedless" innovative architectures avoid the tapping of hot and pressurized air from engine compressors increasing the engine efficiency [27]. When standard bleed ECS requires more the necessary airflow, the bleedless one produce the exact amount of airflow by means of electric driven compressors resulting in a reduction in engine SFC and power required. Indeed, less required fuel entails reductions of fuel costs per hour of flight, although this innovative architecture could cause a drag rise due to the dedicated air intakes. The cabin air pressure level is another parameter assessed by the systems designer in accordance with the aerostructures specialist. This value affects the fatigue life of the fuselage, but higher values make the cabin internal environment more comfortable for the passengers [28]. The passengers comfort is also (negatively) affected by the percentage of air recirculation in cabin, but this parameter improves the engine efficiency, lowering the required secondary power.

Another system that deeply influences the entire aircraft development is the Ice Protection System (IPS) (see Table 8). How this system affects the other design disciplines depends on the type of architecture chosen by the system's designer. High pressurized hot air tapped from the engines is employed in a conventional aerothermal anti-ice system. Alternatively, bled airflow is routed in rubber boots mounted on the wing leading edges. These boots break ice accretions by cyclically inflating and deflating. The airflow required by these two architectures influences by performances of the propulsion system. Otherwise, the IPS could be electric, heating the leading edge with electrical resistors [29]. In this case, the engine is not affected by the air bleed, but a sensitive percentage of mechanical power is extracted and transformed in electric power, hence improving 
the efficiency of the propulsion system. However, this innovative architecture affects the aircraft drag, in the same way of the boots system since they are both additional surface applied on wing and tail leading edge. This produces a modification of the designed airfoil increasing drag. Only the traditional aerothermal protection system has not negative effects on the aerodynamics. Moreover, the IPS can affect the aircraft operation, since, depending on the quantities of protected surfaces, the aircraft is allowed, or not, to operate in the known ice condition or a probable ice condition area.

Once all the power consuming system have been sized, the system specialist designs the Electric and Hydraulic Power Generation and Distribution Systems. Two main design choices could be made in the sizing of those systems. The first one is relative to hydraulic pressure or electric voltage supply, influencing the weight of the entire systems and hence the structural design. The latter is relative to the number of lines and the main equipment, namely hydraulic pumps and electric generators. Obviously, this quantity affects the resulting weight, but effects on the aircraft safety are also present. Lastly, maintenance hours are proportional to the number of components.

Table 7. Environmental control system design variables in aircraft preliminary design. Effects on aircraft design disciplines [own study]

\begin{tabular}{|l|l|l|l|l|l|}
\hline $\begin{array}{l}\text { Environmental } \\
\text { Control System }\end{array}$ & Aerodynamics & $\begin{array}{l}\text { Aerostructural } \\
\text { design }\end{array}$ & $\begin{array}{l}\text { Flight control, } \\
\text { stability and } \\
\text { performance }\end{array}$ & Propulsion & RAMS / Cost \\
\hline $\begin{array}{l}\text { CAU technology } \\
\text { (standard / } \\
\text { bleedless) }\end{array}$ & $\begin{array}{l}\bullet \text { Drag due to } \\
\text { air intakes }\end{array}$ & & $\bullet$ Fuel weight & $\begin{array}{l}\bullet \text { Engine } \\
\text { efficiency }\end{array}$ & $\begin{array}{l}\bullet \text { Fuel cost per } \\
\text { FH }\end{array}$ \\
\hline $\begin{array}{l}\text { Cabin pressure } \\
\text { during cruise }\end{array}$ & & $\bullet$ Cabin load & & $\begin{array}{l}\bullet \text { Bleed air or } \\
\text { electric power } \\
\text { required }\end{array}$ & $\begin{array}{l}\bullet \text { Passenger } \\
\text { comfort }\end{array}$ \\
\hline $\begin{array}{l}\text { \% of } \\
\text { recirculating air }\end{array}$ & & & $\begin{array}{l}\text { Bleed air or } \\
\text { electric power } \\
\text { required }\end{array}$ & $\begin{array}{l}\bullet \text { Passenger } \\
\text { comfort }\end{array}$ \\
\hline
\end{tabular}

Table 8. Ice protection system design variables in aircraft preliminary design. Effects on aircraft design disciplines [own study]

\begin{tabular}{|c|c|c|c|c|c|}
\hline $\begin{array}{l}\text { Ice Protection } \\
\text { System }\end{array}$ & Aerodynamics & $\begin{array}{l}\text { Aerostructural } \\
\text { design }\end{array}$ & $\begin{array}{l}\text { Flight control, } \\
\text { stability and } \\
\text { performance }\end{array}$ & Propulsion & RAMS / Cost \\
\hline $\begin{array}{l}\text { Ice protection } \\
\text { technology } \\
\text { (standard, } \\
\text { bleedless, } \\
\text { boots) }\end{array}$ & $\begin{array}{l}\text { Additional } \\
\text { drag from } \\
\text { leading edge } \\
\text { IPS (for boots } \\
\text { and bleedless) }\end{array}$ & & $\begin{array}{l}\text { Flight } \\
\text { operation } \\
\text { limitation }\end{array}$ & $\begin{array}{l}\text { Bleed air or } \\
\text { electric power } \\
\text { required }\end{array}$ & \\
\hline
\end{tabular}


Table 9. Power generation and distribution system design variables in aircraft preliminary design. Effects on aircraft design disciplines [own study]

\begin{tabular}{|l|l|l|l|l|l|}
\hline $\begin{array}{l}\text { Power } \\
\text { generation and } \\
\text { distribution } \\
\text { (both } \\
\text { Hydraulic and } \\
\text { Electric) }\end{array}$ & Aerodynamics & $\begin{array}{l}\text { Aerostructural } \\
\text { design }\end{array}$ & $\begin{array}{l}\text { Flight control, } \\
\text { stability and } \\
\text { performance }\end{array}$ & Propulsion & RAMS / Cost \\
\hline $\begin{array}{l}\text { Supply voltage / } \\
\text { pressure }\end{array}$ & & $\bullet$ System & & & \\
\hline $\begin{array}{l}\text { Number of lines } \\
\text { and generators / } \\
\text { pumps }\end{array}$ & & $\bullet$ System & & & $\begin{array}{l}\bullet \text { Component } \\
\text { cost }\end{array}$ \\
\hline & $\begin{array}{l}\text { weight } \\
\text { (redundancy) } \\
\text { A/C } \\
\text { maintenance } \\
\text { (component } \\
\text { number) }\end{array}$ \\
\hline
\end{tabular}

\section{CONCLUSIONS}

In this work, the influence on the Overall Aircraft Design of the design variables of the on-board systems design discipline have been remarked and described. As the overall systems mass typically represents almost the $30 \%$ of the aircraft empty weight, it is important to give the proper emphasis to this discipline already from the conceptual design phases. This papers has demonstrated, indeed, that systems design choices affect the entire project since the first phases of the aircraft development, even if simpler design methodologies are employed. Furthermore, the effects deriving from systems sizing are extremely remarkable in the preliminary phase of the design. Every aircraft design discipline, hence structure, aerodynamics, aeroelasticity, flight mechanics, propulsion, RAMS and costs, is deeply affected by on-board systems design variables.

All those considerations about the effects of systems design on the overall aircraft assume particular importance in a collaborative multidisciplinary design, in which optimization problems are posed to produce the best possible aircraft, i.e. with minimum MTOM or minimum DOCs Collaborative design environments (an example is given in [30]) are still currently under study with the aim of joining together in a harmonic way every design specialty, reducing the MDO process. A proper selection of the systems design space would definitely enhance the MDO problem, contributing to a design better product in less time with a smaller effort.

Finally, a key aspect of the current study is represented by the analyses of the effects of innovative architectures that, together with the conventional ones, make this work as more comprehensive as possible.

\section{ACKNOWLEDGMENT}

This work is carried out within AGILE H2020 European research project [2] of which, one of the main purposes is the employment of MDO techniques to enhance the project competitiveness of standard and innovative aircraft configurations. 


\section{REFERENCES}

[1] Liersch, C. M., Hepperle M. 2011, “A distributed toolbox for multidisciplinary preliminary aircraft design", CEAS Aeronautical Journal, pp. 57-68, 2011.

[2] "AGILE - Aircraft 3rd Generation MDO for Innovative Collaboration of Heterogeneous Teams of Experts“, [Online]. Available: http://www.agile-project.eu/.

[3] "SimSAC project flyer," [Online]. Available: http://www.transport-research.info/sites/default/ files/project/documents/20120921_105849_29226_SimSAC-Flyer.pdf.

[4] Kesseler E., Guenov M, 2010, “Advances in Collaborative Civil Aeronautical Multidisciplinary Design Optimization”, American Institute of Aeronautics and Astronautics.

[5] Baalbergen E., Kanakis A., Vankan W., 2009, "A practical approach for coordination of multi-partner engineering jobs in the design of small aircraft", CESAR Special Issue of Journal Czech Aerospace Proceedings, vol. 3.

[6] Coleman P., 2012, "Innovations in collaborative modelling and simulation to deliver the Behavioural Digital Aircraft, CRESCENDO Forum Participants Handbook.”, Toulouse.

[7] TOICA Consortium, "EU FP7 TOICA Project public web page", [Online]. Available: http://www.toica-fp7.eu/.

[8] Sobieszczanski-Sobieski, J., 1995, "Multidisciplinary Design Optimization: An Emerging New Engineering Discipline", Advances in Structural Optimization, pp. 483-496.

[9] Martins, J. R., Lambe, A. B., 2013, "Multidisciplinary Design Optimization: A Survey of Architectures", AIAA Journal, 9(51), pp. 2049-2075.

[10] Liscouët-Hanke, S., 2008, “A Model-Based Methodology for Integrated Preliminary Sizing and Analysis of Aircraft Power System Architectures", Doctoral Thesis.

[11] Scholz, D., 2009, "Aircraft Systems Overview - Greening of Secondary Power Systems", SWAFEA - Sustainable Way for Alternative Fuels and Energy for Aviation, Brussels, Belgium, 23-24 April 2009.

[12] Scholz, D., 2002, “Aircraft Systems - Reliability, Mass, Power and Costs”, EWADE.

[13] Chakraborty, I., Mavris, D. N., 2016, "Integrated Assessment of Aircraft and Novel Subsystem Architectures in Early Design", AIAA SciTech.

[14] Martins Pires, R. M., Lajux, V., Fielding, J. P., 2016, "Methodology for the design and evaluation of wing leading edge and trailing edge devices", ICAS, Hamburg, Germany.

[15] Raymer, D.P., 2012, “Aircraft Design: A Conceptual Approach (5thEdition)“, American Institute of Aeronautics and Astronautics, Washington, DC.

[16] Roskam, J., 2003, “Airplane Design Part I: Preliminary Sizing of Airplanes (2ndEdition)“, DARcorporation, Lawrence, KS.

[17] Torenbeek, E., 1976, "Synthesis of subsonic airplane design“, Nijgh-Wolters-Noordhoff, Rotterdam.

[18] Fioriti, M., 2014, "Adaptable conceptual aircraft design model”, Advances In Aircraft and Spacecraft Science, vol. 1, pp. 43-67.

[19] Rosero, J. A., Ortega, J. A., Aldabas, E., 2007, “Moving towards a more electric aircraft", IEEE Aerospace and Electronic Systems Magazine, vol. 22, n. 3, pp. 3-9.

[20] Jones, R. I., 2002, “The more electric aircraft - assessing the benefits", Proceedings of the Institution of Mechanical Engineers, Part G Journal of Aerospace Engineering, vol. 216, pp. 259-269. 
[21] Berlowitz, I., 2010, “All/More Electric Aircraft Engine \& Airframe Systems Implementation”, The 9th Israeli Symposium on Jet Engines and Gas Turbines.

[22] Heney, P. J., 2002, “A380 pushes 5000 psi into realm of the common man”, Hydraulics \& Pneumatics.

[23] Longxian, X., 2009, "Actuation technology for Flight Control System - Master Thesis", Cranfield University.

[24] Van Den Bossche, D., 2006, "The A380 flight control electrohydrostatic actuators, achievements and lessons learnt”, ICAS, Hamburg, Germany.

[25] Tagge, G. E., Irish L. A., Bailey, A. R., 1985, “Systems Study for an Integrated Digital/Electric Aircraft (IDEA)", NASA Contractor Report 3840, Hampton (VA).

[26] Sinnet, M., 2007, “787 No-Bleed Systems: Saving Fuel and Enhancing Operational Efficiencies", Aero Quarterly QTR_04 | 07, 06-11.

[27] Mecham, M., 2005, "Boeing 787 Technology. Evolution and revolution”, Aviation week \& Space technology, vol. 162, n. 13, pp. 46-50.

[28] Baird, F., 2015, "Dreamliner Cabin Pressure Tech Reduces Altitude Sickness, Benefits PaxEx", Airline passenger experience, apex association.

[29] Meier O. e Scholz D., 2010, "A handbook method for the estimation of power requirements for electrical de-icing systems", Aero - Aircraft Design and Systems Group.

[30] Ciampa, P. D., Nagel, B., 2016, “Towards the 3rd generation MDO collaborative environment”, ICAS.

\section{ACRONYMS}

$\mathrm{AC}$

$\mathrm{ACM}$

AEW

AFDS

CAU

C.G.

DC

ECS

EW

FBW

FOD

FMS

IPS

MDO

MTOM

OAD

OEM

RAMS

SFC

STOL

UAV
Alternate voltage

Air cycle machine

Airborne early warning

Autopilot / Flight director system

Cold air unit

Center of gravity

Direct current

Environmental control system

Early warning

Fly by wire

Foreign object debris

Flight management system

Ice protection system

Multidisciplinary design optimization

Maximum takeoff mass

Overall aircraft design

Operating empty weight

Reliability Availability Maintainability Safety

Specific fuel consumption

Short takeoff and landing

Unmanned aerial vehicle 


\section{PROJEKT WSTĘPNY PODSYSTEMÓW W RAMACH OPTYMALIZACJI MULTIDYSCYPLINARNEJ}

\section{Streszczenie}

Projektowanie samolotówjest tematem złożonym i z jednym z powodów, dla których istnieje kilka zupełnie różnych dyscyplin dizajnerskich zaangażowanych $\mathrm{w}$ ten projekt. Czynionych jest wiele prób w celu optymalizacji tego projektu próbującego rozważyć wszystkie dyscypliny razem na tym samym poziomie uszczegółowienia. Wraz ze zbliżającym się badaniem H2020 AGILE, proces MDO ( Mulidyscyplinarnej Optymalizacji Projektowania) będzie zaczęty i połączy on kilka narzędzi projektowych i kompetencji razem. Każde narzędzie obejmuje inną dziedzinę projektowania taką jak: aerodynamika, struktura, napędy i systemy. The artykuł koncentruje się na integracji podsystemów dyscyplin projektowych $\mathrm{z}$ innymi celem uzyskania completnych i zoptymalizowanych wstępnych projektów samolotów. Wszystkie parametry projektowania użyte do zintegrowania podsystemowych gałęzi z innymi są przedyskutowane jako ich redefinicja $\mathrm{z}$ różnymi poziomami detalu projektu.

Słowa kluczowe: Multidyscyplinarna Optymalizacja Projektowa, Podsystemowy Projekt Statków Powietrznych, Projektowanie Parametrów Przestrzeni. 